Interfaces Against Pollution 2014

\title{
Preparation of a manganese dioxide/carbon fiber electrode for electrosorptive removal of copper ions from water
}

\author{
Chengzhi Hu, Fangyuan Liu, Huachun Lan, Huijuan Liu*, Jiuhui Qu \\ Key Laboratory of Drinking Water Science and Technology, Research Center for Eco-Environmental Sciences, Chinese Academy of Sciences, Beijing 100085, China
}

\section{A R T I C L E I N F O}

\section{Article history:}

Received 13 October 2014

Accepted 11 December 2014

Available online 5 January 2015

\section{Keywords:}

Electrosorption

Capacitive deionization

Manganese dioxide

Heavy metal

Wastewater

\begin{abstract}
A B S T R A C T
$\mathrm{MnO}_{2}$ is an effective adsorbent for many metal ions and a promising electrode material for electrochemical supercapacitors. In this paper, we successfully combined the two functions through preparing a $\mathrm{MnO}_{2}$ /carbon fiber (CF) composite as an electrosorptive electrode. The thin $\mathrm{MnO}_{2}$ film was deposited onto $\mathrm{CF}$ by an anodic eletrodeposition method. The $\mathrm{MnO}_{2} / \mathrm{CF}$ electrodes had ideal pseudocapacitive behavior and high capacitive reversibility. The specific capacitance of the $\mathrm{MnO}_{2} / \mathrm{CF}$ electrode reached a maximum value of $387 \mathrm{~F} / \mathrm{g}$, which is quite competitive compared with literature values. At $0.8 \mathrm{~V}$ applied potential, the maximum $\mathrm{Cu}^{2+}$ adsorption capacity of the $\mathrm{MnO}_{2} / \mathrm{CF}$ electrode was $172.88 \mathrm{mg} / \mathrm{g}$, which is more than 2 times higher than common $\mathrm{MnO}_{2}$ adsorbents without an electric field imposed. SEM images showed that $\mathrm{MnO}_{2}$ nanoflowers with several "petals" were uniformly distributed on the CF surface. Enhancement of adsorption by the polarization potential and the unique microstructure of the deposited $\mathrm{MnO}_{2}$ may be the source of the outstanding adsorption ability of the $\mathrm{MnO}_{2} / \mathrm{CF}$ electrode. The $\mathrm{MnO}_{2} / \mathrm{CF}$ electrode could be regenerated quickly by reversing the voltage. The deposition time of $1000 \mathrm{~s}$ was optimum for achieving maximum capacitance and $\mathrm{Cu}^{2+}$ removal performance. The $\mathrm{MnO}_{2} / \mathrm{CF}$ composite electrosorptive electrode is a promising candidate for $\mathrm{Cu}^{2+}$ removal from aqueous solution.
\end{abstract}

(C) 2014 Elsevier Inc. All rights reserved.

\section{Introduction}

Electrosorption is a separation technology combining adsorption and electrochemical methods, used to remove ionic contaminants such as salt ions [1,2], heavy metal ions [3-6], anions [7], and organics $[8,9]$ from water, and has received extensive attention and support due to its advantages of both waste minimization and reduced processing costs. It has been generally defined as potential-induced adsorption on the surface of charged electrodes. During the electrosorption process, ionic contaminants in the aqueous solution will move towards the oppositely charged electrode under the imposed electric field, and withdraw back to the solution if the electric field is removed or reversed. The working principle of electrosorption is similar to that of an electrochemical capacitor. It has been believed that the physical properties and structure of the electrode materials dominate their electrosorptive performance $[10,11]$. Various forms of carbon are the most widely

\footnotetext{
* Corresponding author. Fax: +86 1062849160.

E-mail address: hjliu@rcees.ac.cn (H. Liu).
}

used electrode materials for electrosorption technology [5,10,12] and electrochemical capacitors [13,14].

Manganese dioxide $\left(\mathrm{MnO}_{2}\right)$ is a one of the most important scavengers of trace metals in the environment, and has been extensively studied as an effective adsorbent to remove heavy metals from water [15-17]. Apart from its excellent heavy metal uptake capacity, $\mathrm{MnO}_{2}$ is a promising electrode material for electrochemical supercapacitors because of its high specific capacitance, good cycle stability, low cost, eco-friendly nature and abundant availability $[18,19] . \mathrm{MnO}_{2}$ possesses a large theoretical capacitance value $(1370 \mathrm{~F} / \mathrm{g})$, which significantly exceeds those of carbonbased materials, resulting in great interest in the development of $\mathrm{MnO}_{2}$-based materials as electrochemical supercapacitor electrodes. However, the capacitance of $\mathrm{MnO}_{2}$ electrodes is ultimately limited by poor electrical conductivity. A way to overcome this drawback is to deposit a thin $\mathrm{MnO}_{2}$ layer on the surface of carbon materials such as carbon nanofiber [20], carbon cloth [21], carbon nanotubes [22], carbon aerogel [23], and graphene [24].

$\mathrm{MnO}_{2} /$ carbon composite materials have also shown great adsorption ability for the removal of heavy metal ions from waste water $[16,25,26]$. Therefore, $\mathrm{MnO}_{2}$ is not only an effective adsor- 
bent for many metal ions but also a promising electrode material for electrochemical supercapacitors. Recently, some researchers $[11,27]$ synthesized $\mathrm{MnO}_{2}$ /nanoporous carbon and $\mathrm{MnO}_{2}$ /graphene composites and successfully used them as electrodes in electrosorptive desalination. However, no previous study has combined the two properties and used $\mathrm{MnO}_{2}$ /carbon composite materials as electrodes to remove metal ions through the electrosorption process. $\mathrm{MnO}_{2}$ /carbon composite materials show great potential as electrodes for the electrosorptive removal of heavy metal ions from water.

In the present study, a simple and cost-effective electroplating approach was used to directly deposit a thin $\mathrm{MnO}_{2}$ layer on the surface of carbon fiber (CF). The surface morphology, structure and capacitive properties of the prepared $\mathrm{MnO}_{2} / \mathrm{CF}$ electrode based on deposited $\mathrm{MnO}_{2}$ were characterized. We evaluated the electrosorptive performance of the $\mathrm{MnO}_{2} / \mathrm{CF}$ electrode on $\mathrm{Cu}^{2+}$ removal. The effect of $\mathrm{MnO}_{2}$ mass loading, cell voltage, and $\mathrm{pH}$ on $\mathrm{Cu}^{2+}$ removal by the electrosorptive electrode were also examined.

\section{Materials and methods}

\subsection{Preparation of the $\mathrm{MnO}_{2} / \mathrm{CF}$ electrode}

A commercially available CF (A090, TORAY, Japan) was used as the supporting material for $\mathrm{MnO}_{2} \cdot \mathrm{MnO}_{2}$ was electrodeposited onto $\mathrm{CF}$ by the galvanostatic method with a three-electrode setup, where $\mathrm{CF}$, graphite and $\mathrm{Hg} / \mathrm{HgCl}_{2}$ were used as working electrode, counter electrode and reference electrode, respectively. An aqueous precursor solution with $0.1 \mathrm{~mol} / \mathrm{L} \mathrm{MnSO}_{4}$ and $0.01 \mathrm{~mol} / \mathrm{L}$ $\mathrm{H}_{2} \mathrm{SO}_{4}$ was used as the electrolyte, and the deposition was performed at a constant current of $0.5 \mathrm{~mA} / \mathrm{cm}^{2}$. The $\mathrm{MnO}_{2}$ mass loading was controlled by varying the deposition time from 0 to $7200 \mathrm{~s}$, and was evaluated by calculating the weight difference of the working electrodes. To ensure that the deposition of $\mathrm{MnO}_{2}$ took place uniformly and firmly on the CF surface, the CF was treated with $5 \% \mathrm{HNO}_{3}$ solution at $80{ }^{\circ} \mathrm{C}$ for $30 \mathrm{~min}$ before the deposition. Typically, the area of the working electrode was $3 \times 2 \mathrm{~cm}^{2}$. After the deposition, the working electrodes were washed with distilled water and then dried at $105^{\circ} \mathrm{C}$ for $5 \mathrm{~h}$.

\subsection{Materials characterization}

The surface morphology of the $\mathrm{MnO}_{2} / \mathrm{CF}$ electrodes was examined using an ultra-high resolution field emission scanning electron microscopy (FE-SEM, SU 8020, Hitachi, Japan). The crystal structure of the $\mathrm{MnO}_{2} / \mathrm{CF}$ electrodes and CF was determined by an X-ray powder diffractometer (X'Pert PRO MPD, PANalytical, Netherland) with copper $K \alpha$ radiation. The XRD patterns of the samples were recorded between $10^{\circ}$ and $80^{\circ}(2 \theta)$ at a scan step size of $0.026^{\circ}$, and a time per step of $58.14 \mathrm{~s}$. Chemical state analysis of the deposited $\mathrm{MnO}_{2}$ was carried out by X-ray photoelectron spectroscopy (XPS) using an ESCALAB 250 X-ray photoelectron spectrometer. All XPS spectra were corrected using the $C 1 \mathrm{~s}$ line at $284.6 \mathrm{eV}$, to investigate the components of the as-prepared samples and the valence of $\mathrm{Mn}$.

\subsection{Electrochemical evaluation}

Electrochemical characteristics of the $\mathrm{MnO}_{2} / \mathrm{CF}$ electrodes prepared at different deposition periods were evaluated by using cyclic voltammetry (CV) and galvanostatic charge/discharge methods with a CHI660C electrochemical workstation (ChenHua, China) at ambient temperature. All electrochemical measurements were carried out in $1 \mathrm{M} \mathrm{Na}_{2} \mathrm{SO}_{4}$ aqueous electrolyte solutions. $\mathrm{CV}$ was performed at scanning rates of $5 \mathrm{mV} / \mathrm{s}$ and $50 \mathrm{mV} / \mathrm{s}$ with a poten- tial window from 0 to $1.0 \mathrm{~V}$. Galvanostatic charge/discharge tests were measured at a current density of $0.1 \mathrm{~A} / \mathrm{g}$. The specific capacitance $(\mathrm{C}, \mathrm{F} / \mathrm{g}$ ) was calculated according to the following equation (Eq. (1)) [11,21]:

$C=\frac{I \Delta t}{m \Delta V}$

where $m(\mathrm{~g})$ is the mass of $\mathrm{MnO}_{2}$ loaded, $\Delta V(\mathrm{~V})$ is the potential window, $I(\mathrm{~A})$ is the charge-discharge current, and $\Delta t(\mathrm{~s})$ is the charge-discharge time.

\subsection{Performance of $\mathrm{Cu}^{2+}$ removal by electrosorption}

A schematic diagram of the static state electrosorption system is shown in Fig. 1. The experimental apparatus included an electrosorption tank, a pH meter, and a DC power supply. The working electrode was two $\mathrm{MnO}_{2} / \mathrm{CF}$ electrodes as cathodes, and three pieces of CF sheet were used as anodes for the opposite electrode. The distance between each anode/cathode pair was $5 \mathrm{~mm}$. In each experiment, the total solution volume was $200 \mathrm{~mL}$. All experiments were performed with $\mathrm{Cu}\left(\mathrm{NO}_{3}\right)_{2}$ solutions. The $\mathrm{Cu}^{2+}$ removal was performed with a constant voltage of $-0.8 \mathrm{~V} .2 \mathrm{~mL}$ samples were withdrawn at predetermined time intervals to determine the $\mathrm{Cu}^{2+}$ concentration using an ICP-OES instrument (P700 series, Agilent, USA). The solution $\mathrm{pH}$ was continuously monitored with a $\mathrm{pH}$ meter (UB-7, Denver, USA) and adjusted using $\mathrm{NaOH}$ or $\mathrm{HCl}$ solution.

Electrosorptive experiments with $\mathrm{MnO}_{2} / \mathrm{CF}$ electrodes prepared at different deposition times, which yielded different $\mathrm{MnO}_{2}$ mass loadings, was carried out at a constant initial $\mathrm{Cu}^{2+}$ concentration of $6 \mathrm{mg} / \mathrm{L}$ with the above apparatus. The amount of $\mathrm{Cu}^{2+}$ adsorbed on the $\mathrm{MnO}_{2} / \mathrm{CF}$ electrodes at electro-adsorption equilibrium was calculated according to Eq. (2):

$q_{t}=\frac{\left(C_{0}-C_{\mathrm{e}}\right) V}{m}$

where $q_{\mathrm{t}}(\mathrm{mg} / \mathrm{g})$ is the amount of $\mathrm{Cu}^{2+}$ adsorbed on the $\mathrm{MnO}_{2} / \mathrm{CF}$ electrode at time $t(\mathrm{~min}) ; C_{0}$ and $C_{\mathrm{e}}(\mathrm{mg} / \mathrm{L})$ are the initial and equilibrium concentrations of $\mathrm{Cu}^{2+}$ in the solution, respectively; $V(\mathrm{~L})$ is the volume of the solution; $m(\mathrm{~g})$ is the amount of $\mathrm{MnO}_{2}$ loaded onto the composite electrode.

Langmuir and Freundlich isotherms [4] were used to validate the experimental data for the electrosorption of $\mathrm{Cu}^{2+}$. Kinetic experiments were performed to determine the rate of $\mathrm{Cu}^{2+}$ ion removal from the water by the $\mathrm{MnO}_{2} / \mathrm{CF}$ electrodes. A pseudo-first order (Lagergren's equation) kinetic model was employed to fit the experimental data [10].

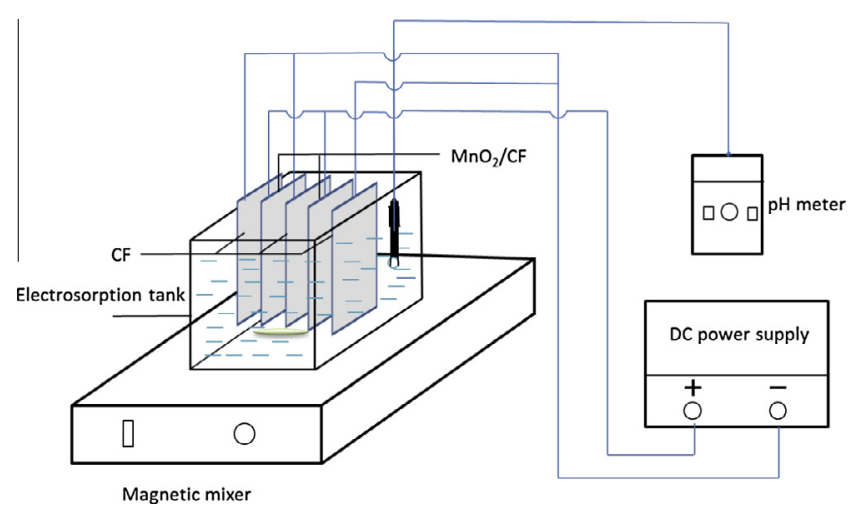

Fig. 1. Schematic diagram of static adsorption/electrosorption apparatus. 


\section{Results and discussions}

\subsection{Morphological and structural characterization}

Fig. 2 presents the SEM images of $\mathrm{CF}$ and the $\mathrm{MnO}_{2} / \mathrm{CF}$ electrode with deposition time of $1000 \mathrm{~s}$. It can be seen that the smooth surface of CF (Fig. 2a) had been uniformly covered by a clustered substance with the size about $200 \mathrm{~nm}$. The EDX results (Fig. 2e and f) show that the surface composition of the electrochemically deposited electrodes was composed of the elements C, O and Mn, which confirmed that the nano-clusters were manganese oxides. As shown in Fig. 2c, each nano-cluster was comprised of irregular sheets to form a petal-like nanostructure. These nano-sized $\mathrm{MnO}_{2}$ clusters exhibited microporous architectures. The clusters appeared to consist of irregular sheets with thickness of a few $\mathrm{nm}$ and width of about $100 \mathrm{~nm}$, which is in accordance with the result of Chen et al. [21]. Such a microstructure ensures outstanding performance in the intercalation/deintercalation of electrolyte cations into electrode materials, and we therefore expect high performance electrosorption.

Fig. 3 shows the XRD patterns for $\mathrm{MnO}_{2} / \mathrm{CF}$ electrodes with deposition time of $1000 \mathrm{~s}$ and $7200 \mathrm{~s}$, as well as that of CF. For all samples, two diffraction peaks appearing around $26^{\circ}$ and $55^{\circ}$ are associated with graphitic carbon. Magnifying the XRD patterns (inset of Fig. 3a), a weak peak at around $37^{\circ}$ that can be assigned to the diffraction peak of birnessite $\mathrm{MnO}_{2}$ (JCPDE 18-0802) can be observed for the two $\mathrm{MnO}_{2} / \mathrm{CF}$ electrodes. The peak intensity increased with the increase of deposition time, which is a result of the increased amount of $\mathrm{MnO}_{2}$ deposited onto CF with longer deposition time. Overall, XRD patterns of the $\mathrm{MnO}_{2} / \mathrm{CF}$ electrodes indicated an amorphous structure for the manganese oxide in the composite. This also contributes to the large surface area of the $\mathrm{MnO}_{2} / \mathrm{CF}$ electrodes. As shown in Fig. $4 \mathrm{a}$, the $\mathrm{Mn} 2 \mathrm{p}_{3 / 2}$ peak is centered at $642.1 \mathrm{eV}$ and $\mathrm{Mn} 2 \mathrm{p}_{1 / 2}$ peak at $653.8 \mathrm{eV}$, with a spinenergy separation of $11.7 \mathrm{eV}$, in good agreement with the reported data for $\mathrm{Mn} 2 \mathrm{p}_{3 / 2}$ and $\mathrm{Mn} 2 \mathrm{p}_{1 / 2}$ in $\mathrm{MnO}_{2}$. The $\mathrm{O}$ 1s spectrum was deconvoluted into three constituents, corresponding to oxygen in the $\mathrm{Mn}-\mathrm{O}-\mathrm{Mn}$ bond $(529 \mathrm{eV})$ of the tetravalent oxide, $\mathrm{Mn}-\mathrm{O}-\mathrm{H}$ bond $(531 \mathrm{eV})$ of $\mathrm{Mn}$ hydroxide, and $\mathrm{H}-\mathrm{O}-\mathrm{H}$ bond $(532 \mathrm{eV})$ of water (Fig. 4b). These results are consistent with the XRD analysis as mentioned above.

\subsection{Electrochemical properties}

The CV responses of the $\mathrm{MnO}_{2} / \mathrm{CF}$ electrodes prepared with various deposition times are shown in Fig. 5, at the specific scan rates of $5 \mathrm{mV} / \mathrm{s}$ and $50 \mathrm{mV} / \mathrm{s}$, respectively. All CV curves in Fig. 5 a have a relatively symmetrical rectangular shape. When the scan rate changed from $5 \mathrm{mV} / \mathrm{s}$ to $50 \mathrm{mV} / \mathrm{s}$ (Fig. $5 \mathrm{~b}$ ), the $\mathrm{CV}$ shapes remained almost rectangular, with only a few deviations for the samples with large deposition time. The anodic and cathodic regimes are essentially mirror-images of each other. The results indicate that the prepared $\mathrm{MnO}_{2} / \mathrm{CF}$ electrodes exhibited ideal pseudocapacitive behavior. The areas enclosed under the CV curves correspond to the energy storage capability of the electrode material. The voltammetric current response increased with the increase of deposition time and was directly proportional to the $\mathrm{MnO}_{2}$ mass loading on the $\mathrm{CF}$ substrates. The results in Fig. 5 suggest that the capacitance of CF was improved by depositing $\mathrm{MnO}_{2}$, and high $\mathrm{MnO}_{2}$ content in the composite electrode contributed to higher charge storage.

The charge/discharge curves of the $\mathrm{MnO}_{2} / \mathrm{CF}$ electrodes prepared with different deposition times at a fixed current density of $0.1 \mathrm{~A} / \mathrm{g}$ are shown in Fig. 6a. The anodic charging segments were generally symmetric to their corresponding cathodic discharging counterparts for all the samples, indicating high reversibility typical of a capacitive material. In addition, the $\mathrm{MnO}_{2} / \mathrm{CF}$ electrodes had an increase of discharge time with increasing deposition time. This ideal electrochemical capacity behavior was also confirmed by the results shown in Fig. 6a. The specific capacitances for the $\mathrm{MnO}_{2} / \mathrm{CF}$ electrodes were calculated from the charge/discharge curves based on the $\mathrm{MnO}_{2}$ mass loading. As shown in Fig. 6b, the capacitances increased with the $\mathrm{MnO}_{2}$ mass loading for deposition
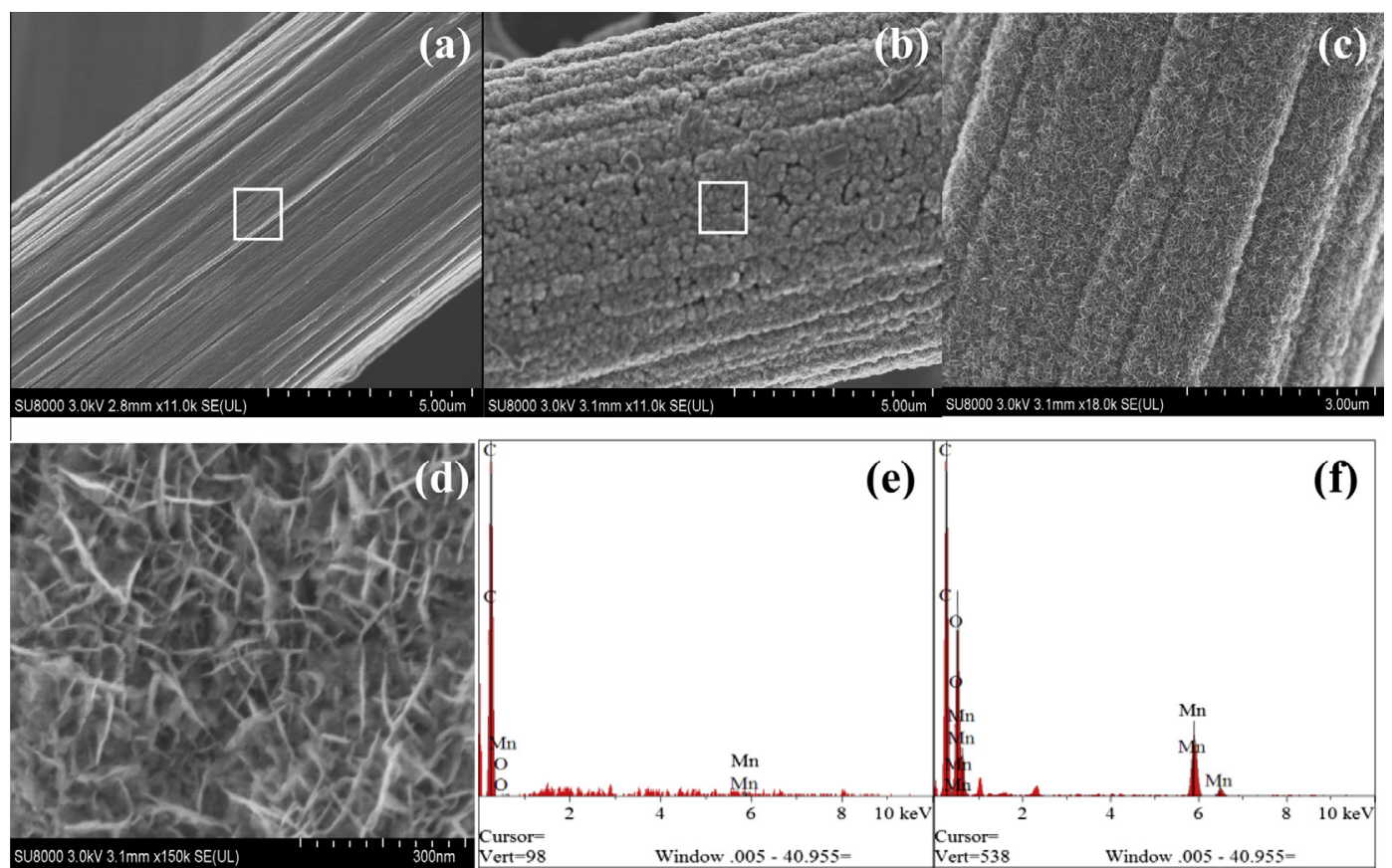

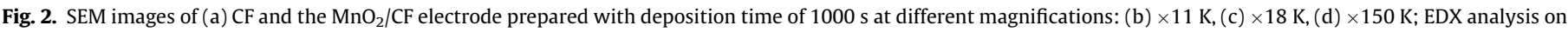
the marked square area of (e) $\mathrm{CF}$ and the (f) $\mathrm{MnO}_{2} / \mathrm{CF}$ electrode with deposition time of $1000 \mathrm{~s}$. 


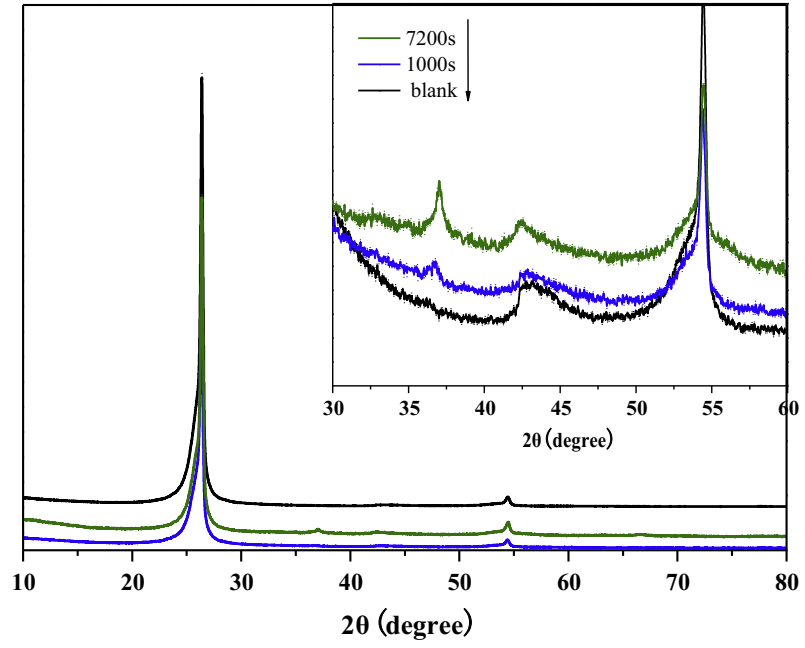

Fig. 3. XRD pattern of $\mathrm{CF}$ (blank) and $\mathrm{MnO}_{2} / \mathrm{CF}$ electrodes with deposition times of $1000 \mathrm{~s}$ and $7200 \mathrm{~s}$.
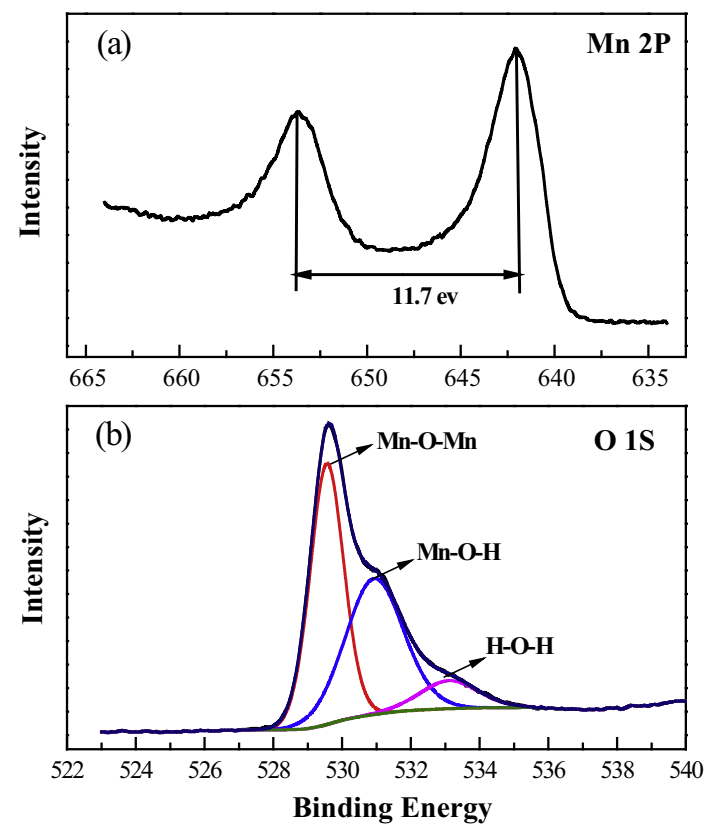

Fig. 4. XPS spectra of (a) Mn 2p core level and (b) O 1 s core level for $\mathrm{MnO}_{2} / \mathrm{CF}$ electrode with deposition time of $1000 \mathrm{~s}$.

times up to $1000 \mathrm{~s}$. The capacitances decreased for deposition times exceeding $1000 \mathrm{~s}$, which is mainly due to aggregation of the $\mathrm{MnO}_{2}$ nanosheets and the limited conductivity of the high mass loading samples [21,22]. The maximal capacitance attained in this study was as high as $387 \mathrm{~F} / \mathrm{g}$, which is quite competitive with literature values [20]. Thus, the deposition time of $1000 \mathrm{~s}$ was optimum for achieving maximum capacitance and acceptable characteristics for application as an electrosorptive electrode.

\subsection{Electrosorptive performance in $\mathrm{Cu}^{2+}$ removal}

Fig. 7 displays both the experimental and modeled electrosorption isotherms of $\mathrm{Cu}^{2+}$ on the $\mathrm{MnO}_{2} / \mathrm{CF}$ electrode at $\mathrm{pH}$ 5. The experimental data were fitted to the well-known Langmuir and Freundlich isotherm models. The weight of deposited $\mathrm{MnO}_{2}$, which is the active component in the composite electrodes, was used as the mass of adsorbent. The estimated isotherm parameters from these

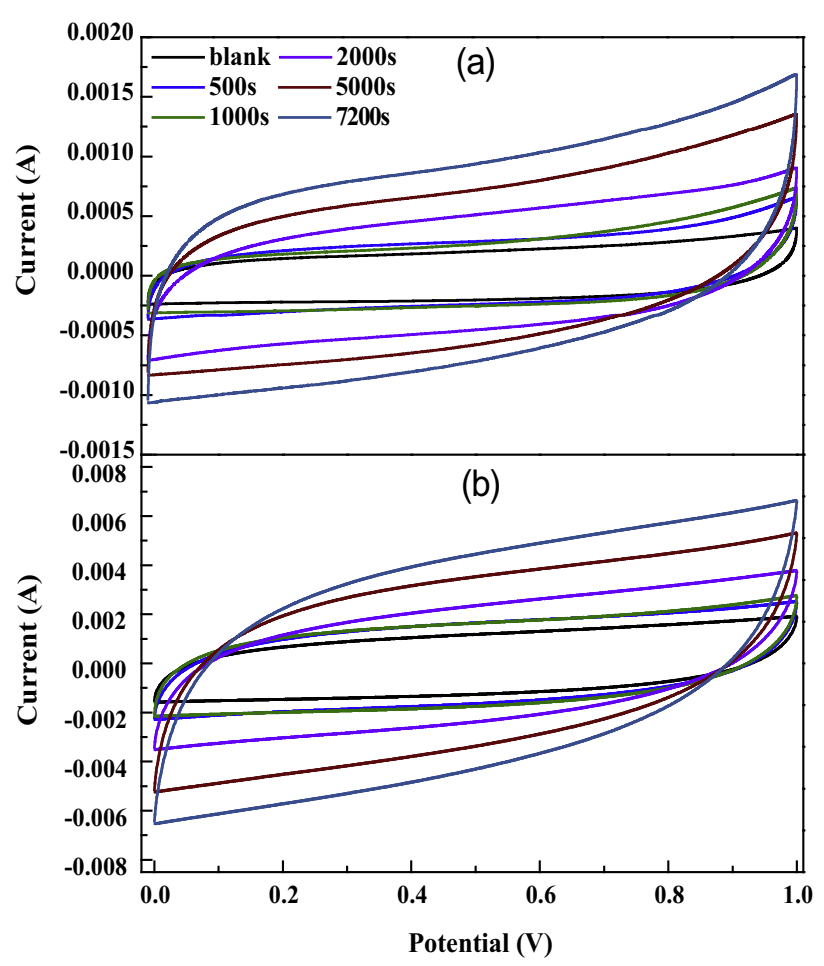

Fig. 5. Cyclic voltammograms of $\mathrm{MnO}_{2} / \mathrm{CF}$ electrodes prepared with different deposition times at scan rates of (a) $5 \mathrm{mV} / \mathrm{s}$ and (b) $50 \mathrm{mV} / \mathrm{s}$.

model fits are summarized in Table 1. It was found that the electrosorption isotherms were consistent with both Langmuir and Freundlich models. At applied potential of $-0.8 \mathrm{~V}$, the maximum adsorption capacity of the $\mathrm{MnO}_{2} / \mathrm{CF}$ electrode was $172.88 \mathrm{mg} / \mathrm{g}$, which is considerably higher than 56.62 and $24.57 \mathrm{mg} / \mathrm{g}$, the reported electrosorptive $\mathrm{Cu}^{2+}$ uptake capacities of ordered mesoporous carbon [10] and activated carbon electrodes [6], respectively. The maximum adsorption capacity of $\mathrm{Cu}^{2+}$ with this composite electrode based on the $\mathrm{MnO}_{2}$ loading is 2.2 times higher than that [28] of $\mathrm{MnO}_{2}$ absorbent without an electric field imposed. This should be ascribed to the enhanced adsorption by the polarization potential and the unique microstructure of the nano- $\mathrm{MnO}_{2}$ generated by the electro-deposition method.

Fig. 8 shows the $\mathrm{Cu}^{2+}$ electrosorption kinetic data fitted with pseudo-first-order equations. The simulated parameters are listed in Table 2. The electrosorption process could be divided into two steps, a quick step and a slow one. In the first step, the electrosorption rate was fast, and over $85 \%$ of the equilibrium adsorption capacity was achieved within $8 \mathrm{~h}$. In the subsequent step, the adsorption was slow. After $12 \mathrm{~h}$, over $96 \%$ of the maximum adsorption had taken place, thus $24 \mathrm{~h}$ was an adequate time for equilibration to occur. The deposition time influenced the rate of $\mathrm{Cu}^{2+}$ removal by electrosorption on the $\mathrm{MnO}_{2} / \mathrm{CF}$ electrode. The electrosorption rate of the $\mathrm{MnO}_{2} / \mathrm{CF}$ electrode with deposition time of near $1000 \mathrm{~s}$ was higher than that with lower (300 s) or greater (5000 s) deposition time. A pseudo-first-order kinetics equation could represent the $\mathrm{Cu}^{2+}$ electrosorption kinetic data well, as evident from the high coefficient of determination $\left(R^{2}\right)$ value.

To examine the regeneration of the $\mathrm{MnO}_{2} / \mathrm{CF}$ electrode, an electrosorption/desorption experiment was conducted at the initial $\mathrm{Cu}^{2+}$ concentration of $5.6 \mathrm{mg} / \mathrm{L}$. After $24 \mathrm{~h}$ running at $-0.8 \mathrm{~V}$, an opposite cell voltage of $0.8 \mathrm{~V}$ was applied in order to desorb the $\mathrm{Cu}^{2+}$. As shown in Fig. 9, the adsorbed $4.6 \mathrm{mg} / \mathrm{L} \mathrm{Cu}^{2+}$ was released from the electrode surfaces back to the solution under the effect of 

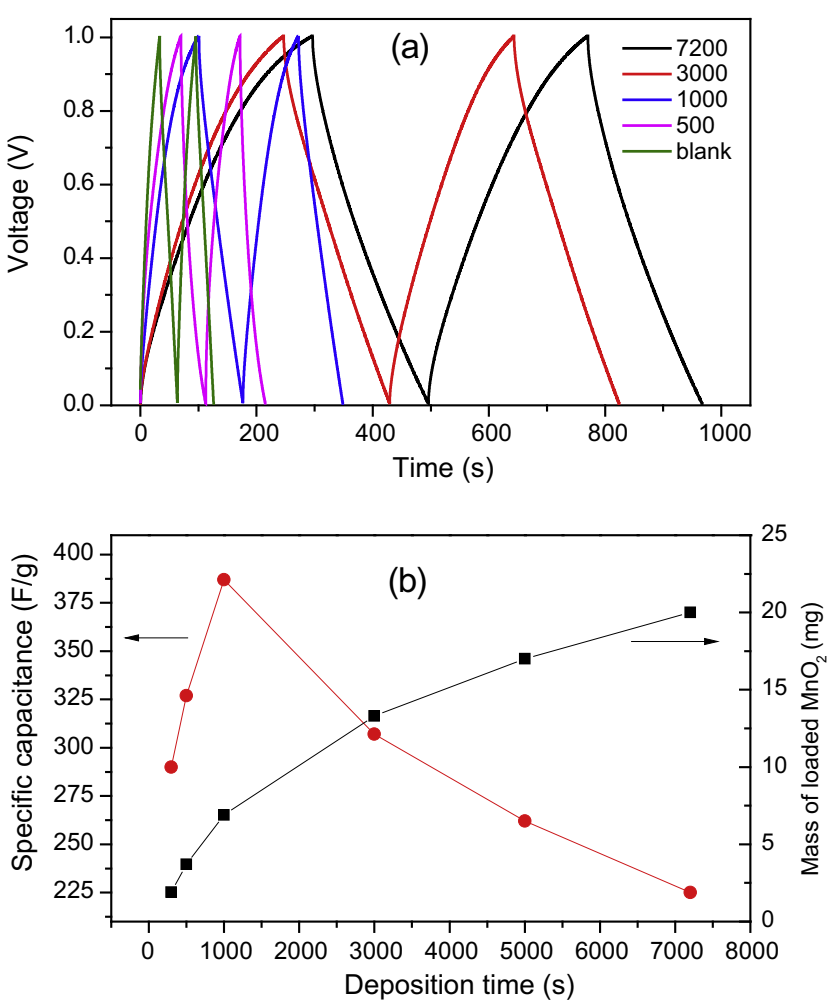

Fig. 6. (a) Galvanostatic charge/discharge curves at the current density of $0.1 \mathrm{~A} / \mathrm{g}$; (b) specific capacitances of $\mathrm{MnO}_{2} / \mathrm{CF}$ electrodes and $\mathrm{MnO}_{2}$ mass loading at different deposition times.

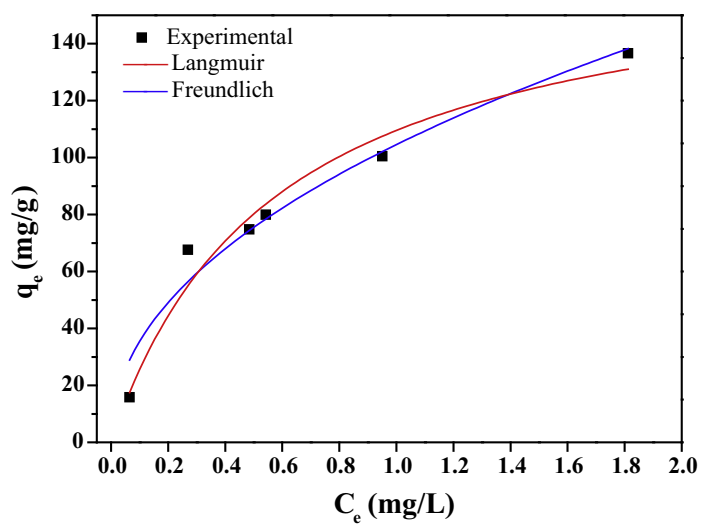

Fig. 7. Electrosorption isotherms of $\mathrm{Cu}^{2+}$ ions on the $\mathrm{MnO}_{2} / \mathrm{CF}$ electrode with Langmuir and Freundlich model correlations. $\mathrm{pH}=5$. Applied voltage $=-0.8 \mathrm{~V}$.

Table 1

Parameters of Langmuir and Freundlich isotherms for $\mathrm{Cu}^{2+}$ electrosorption on the $\mathrm{MnO}_{2} / \mathrm{CF}$ electrode at $\mathrm{pH} 5$ and $-0.8 \mathrm{~V}$ applied voltage.

\begin{tabular}{lllllll}
\hline Freundlich & \multicolumn{6}{l}{ Langmuir } \\
\cline { 1 - 3 } \cline { 5 - 7 }$K_{\mathrm{F}}\left(\mathrm{mg}^{1-1 / \mathrm{n}} \mathrm{L}^{1 / \mathrm{n}} / \mathrm{g}\right)$ & $n$ & $R^{2}$ & & $q_{\mathrm{m}}(\mathrm{mg} / \mathrm{g})$ & $b(\mathrm{~L} / \mathrm{mg})$ & $R^{2}$ \\
\hline 104.56 & 2.13 & 0.95 & & 172.88 & 1.73 & 0.96 \\
\hline
\end{tabular}

reversed voltage, and the $\mathrm{Cu}^{2+}$ recovered in the solution only returned to about $82 \%$ of the adsorbed $\mathrm{Cu}^{2+}$, with the difference corresponding to the equilibrium state of chemisorption. This result implies that $\mathrm{Cu}^{2+}$ ions have a strong affinity for $\mathrm{MnO}_{2}$ $[17,28]$, and also indicates that most $\mathrm{Cu}^{2+}$ ions were electroad-

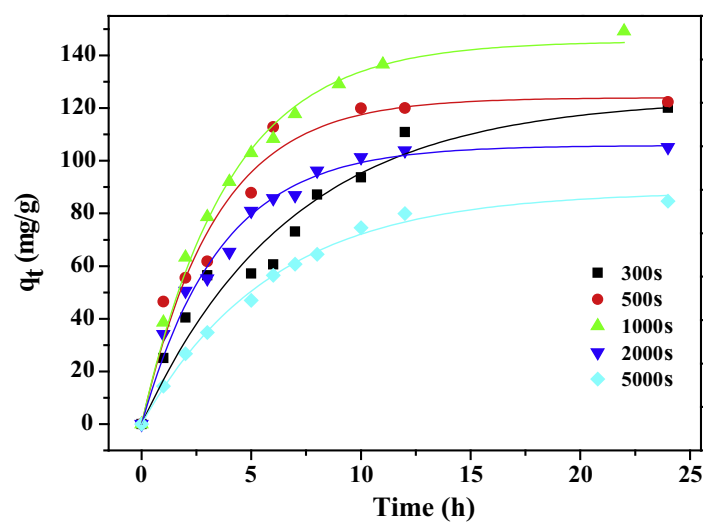

Fig. 8. Effect of contact time on $\mathrm{Cu}^{2+}$ electrosorption by $\mathrm{MnO}_{2} / \mathrm{CF}$ electrodes and fitting plots using the pseudo-first-order equation for $-0.8 \mathrm{~V}$ applied voltage and pH 5. (Symbols) experimental data; (-) pseudo-first-order model fitting.

sorbed by forming an electrical double-layer within the $\mathrm{MnO}_{2} / \mathrm{CF}$ electrode. The regeneration of the $\mathrm{MnO}_{2} / \mathrm{CF}$ electrode can be achieved by applying reversed voltage.

\subsection{Parameter optimization for $\mathrm{Cu}^{2+}$ removal}

The $\mathrm{Cu}^{2+}$ electrosorption removal efficiency was studied using $\mathrm{MnO}_{2} / \mathrm{CF}$ electrodes prepared under different deposition times. As shown in Fig. 10a, longer deposition time favored $\mathrm{Cu}^{2+}$ removal. $\mathrm{The} \mathrm{Cu}^{2+}$ removal efficiency of $\mathrm{CF}$ via electrosorption was significantly enhanced after loading $\mathrm{MnO}_{2}$ onto the electrodes. The $\mathrm{Cu}^{2+}$ removal efficiency of the $\mathrm{MnO}_{2} / \mathrm{CF}$ electrode prepared with deposition time of $1000 \mathrm{~s}$ was twice as high as that of $\mathrm{CF}$ and approximately half that of the $\mathrm{MnO}_{2} / \mathrm{CF}$ electrode prepared with deposition time of $3600 \mathrm{~s}$. This result could be explained by the greater mass of $\mathrm{MnO}_{2}$ loaded on CF with longer deposition time, which could provide the composite electrodes with higher capacitance. The concentration of the released $\mathrm{Mn}^{2+}$ from the electrode was measured during the electrosorption process. It was very low (up to $0.3 \mathrm{mg} / \mathrm{L}$ ) and just accounted for $0.9 \%$ of the loaded $\mathrm{MnO}_{2}$ for the electrode with deposition time of $1000 \mathrm{~s}$. Thus the release of $\mathrm{Mn}^{2+}$ had little influence on the electrosorptive ability of the $\mathrm{MnO}_{2} / \mathrm{CF}$ electrode.

Fig. $10 \mathrm{~b}$ shows the $\mathrm{Cu}^{2+}$ removal by $\mathrm{MnO}_{2} / \mathrm{CF}$ electrodes at five different applied voltages. It was found that the $\mathrm{Cu}^{2+}$ removal efficiency increased from $43 \%$ to $90 \%$ after about 720 min electrosorption, as the voltage shifted from 0 to $1.0 \mathrm{~V}$. As expected, the greater the cell voltage applied, the higher the $\mathrm{Cu}^{2+}$ removal efficiency that could be achieved. It is believed that the flow velocity of electrons is promoted and the electrostatic attraction becomes stronger with increasing applied voltage, resulting in an increase in $\mathrm{Cu}^{2+}$ removal. It indicated that, for the electrosorption process of $1.0 \mathrm{~V}$, about $50 \%$ of removed $\mathrm{Cu}^{2+}$ could be attributed to the adsorption onto the electrode material rather than the effect of electric field. The own adsorption to $\mathrm{Cu}^{2+}$ due to the electrode microstructure contributed at least half the electrosoptive capacity.

The effect of solution $\mathrm{pH}$ on $\mathrm{Cu}^{2+}$ removal was investigated with solution $\mathrm{pH}$ adjusted to 3, 4, 5 and 6. As shown in Fig. 10c, the $\mathrm{Cu}^{2+}$ removal efficiency increased with increasing $\mathrm{pH}$ value. This result could be ascribed the competitive advantage of $\mathrm{Cu}^{2+}$ compared with $\mathrm{H}_{3} \mathrm{O}^{+}$at high solution $\mathrm{pH}$, where the $\mathrm{H}_{3} \mathrm{O}^{+}$concentration is relatively lower. In addition, generally, the surface potential of $\mathrm{MnO}_{2}$ loaded on $\mathrm{CF}$ is more negative at high solution $\mathrm{pH}$, which could lead to a greater electrostatic attraction between $\mathrm{Cu}^{2+}$ and $\mathrm{MnO}_{2}$. 
Table 2

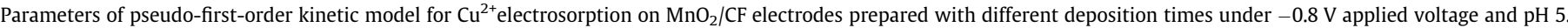

\begin{tabular}{|c|c|c|c|c|c|}
\hline \multirow[t]{2}{*}{ Pseudo-first-order rate parameters } & \multicolumn{5}{|c|}{ Deposition time } \\
\hline & $300 \mathrm{~s}$ & $500 \mathrm{~s}$ & $1000 \mathrm{~s}$ & $2000 \mathrm{~s}$ & $5000 \mathrm{~s}$ \\
\hline$q_{\mathrm{e}}(\mathrm{mg} / \mathrm{g})$ & 123.83 & 123.97 & 145.42 & 105.81 & 88.35 \\
\hline$K_{1}(1 / \mathrm{h})$ & 0.15 & 0.29 & 0.25 & 0.28 & 0.17 \\
\hline$R^{2}$ & 0.95 & 0.96 & 0.99 & 0.98 & 0.99 \\
\hline
\end{tabular}

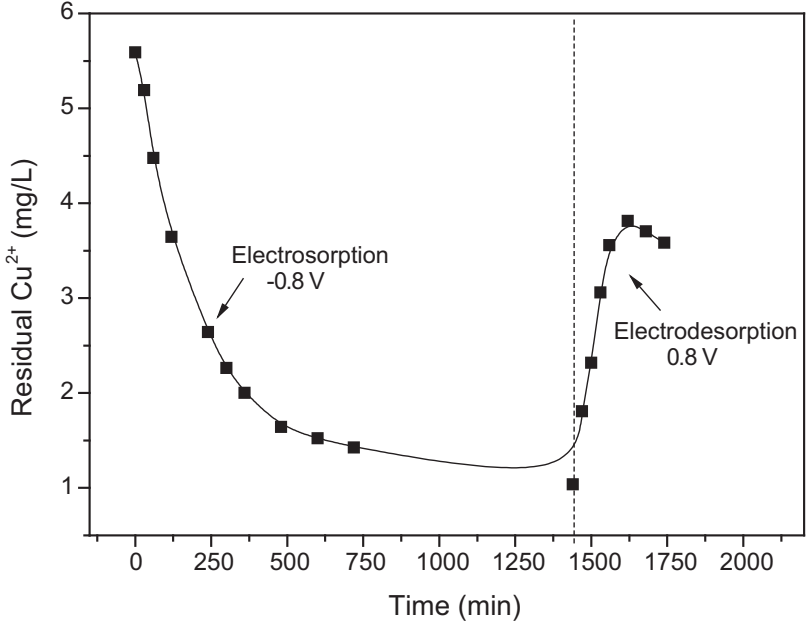

Fig. 9. Electrosorption/desorption profiles of $\mathrm{MnO}_{2} / \mathrm{CF}$ electrodes at $\mathrm{pH} 5$.

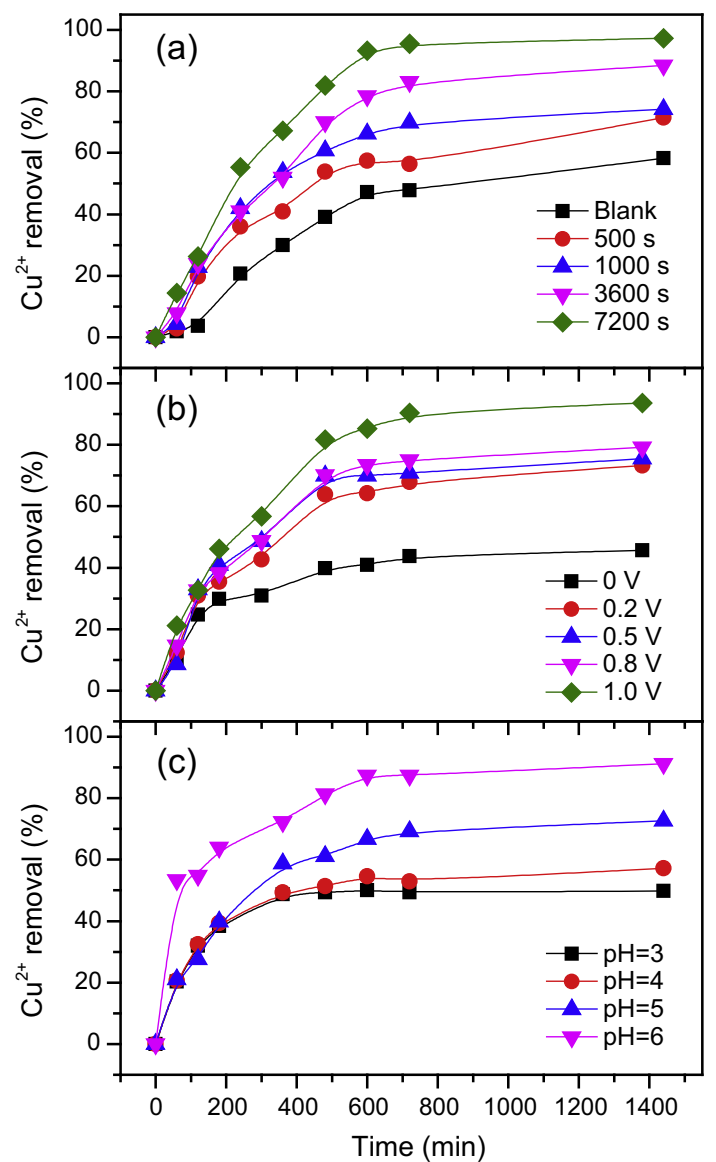

Fig. 10. Effect of (a) deposition time, (b) applied voltage and (c) solution $\mathrm{pH}$ on $\mathrm{Cu}^{2+}$ removal by the $\mathrm{MnO}_{2} / \mathrm{CF}$ electrode. The general experimental conditions of deposition time, applied voltage and solution $\mathrm{pH}$ were $1000 \mathrm{~s},-0.8 \mathrm{~V}$ and $\mathrm{pH} 5$, respectively.

\section{Conclusions}

A $\mathrm{MnO}_{2} / \mathrm{CF}$ electrode has been successfully synthesized by an anodic eletrodeposition method for application in electrosorption. $\mathrm{MnO}_{2}$ nanoflowers with several "petals" were found to be distributed uniformly on the CF surface. The specific capacitance of the $\mathrm{MnO}_{2} / \mathrm{CF}$ electrode based on $\mathrm{MnO}_{2}$ reached a maximum value of $387 \mathrm{~F} / \mathrm{g}$ at the current density of $0.1 \mathrm{~A} / \mathrm{g}$. With $0.8 \mathrm{~V}$ applied potential, the maximum $\mathrm{Cu}^{2+}$ adsorption capacity of the $\mathrm{MnO}_{2} / \mathrm{CF}$ electrode was $172.88 \mathrm{mg} / \mathrm{g}$, which is more than two times higher than common $\mathrm{MnO}_{2}$ absorbent without an electric field imposed. Enhancement of adsorption by the polarization potential and the unique microstructure of the deposited $\mathrm{MnO}_{2}$ may equally contribute the outstanding adsorption ability of the $\mathrm{MnO}_{2} / \mathrm{CF}$ electrode. A pseudo-first-order kinetics equation could represent the $\mathrm{Cu}^{2+}$ electrosorption kinetic data well. The $\mathrm{MnO}_{2} / \mathrm{CF}$ electrode could be regenerated quickly by applying a reversed voltage. The deposition time of 1000s was optimum for achieving maximum capacitance and $\mathrm{Cu}^{2+}$ removal performance. The $\mathrm{Cu}^{2+}$ removal efficiency by electrosorption with the $\mathrm{MnO}_{2} / \mathrm{CF}$ electrode was positively correlated to applied voltage and solution $\mathrm{pH}$. The efficiency of heavy metal removal by the $\mathrm{MnO}_{2} / \mathrm{CF}$ electrode needs to be further evaluated in practical wastewater.

\section{Acknowledgments}

The authors are grateful for financial support from the National Natural Science Foundation of China (Nos. 41171377 and 51225805) and the key project of the National "863" High-tech R\&D Program of China (2012AA062604).

\section{References}

[1] C.J. Gabelich, T.D. Tran, I.H. Suffet, Environ. Sci. Technol. 36 (2002) 3010-3019. [2] C.H. Hou, C.Y. Huang, Desalination 314 (2013) 124-129.

[3] E.J. Bain, J.M. Calo, R. Spitz-Steinberg, J. Kirchner, J. Axen, Energy Fuels 24 (2010) 3415-3421.

[4] C.C. Huang, Y.J. Su, J. Hazard. Mater. 175 (2010) 477-483.

[5] Y. Liu, J. Yan, D. Yuan, Q. Li, X. Wu, Chem. Eng. J. 218 (2013) 81-88.

[6] S.Y. Huang, C.S. Fan, C.H. Hou, J. Hazard. Mater. 278 (2014) 8-15.

[7] A. Afkhami, Carbon 41 (2003) 1320-1322.

[8] O. Kitous, A. Cheikh, H. Lounici, H. Grib, A. Pauss, N. Mameri, J. Hazard. Mater. 161 (2009) 1035-1039.

[9] B. Pierozynski, D. Zielinska, J. Electroanal. Chem. 651 (2011) 100-103.

[10] C.C. Huang, J.C. He, Chem. Eng. J. 221 (2013) 469-475.

[11] J. Yang, L. Zou, H. Song, Z. Hao, Desalination 276 (2011) 199-206.

[12] K.Y. Foo, B.H. Hameed, J. Hazard. Mater. 170 (2009) 552-559.

[13] P. Simon, Y. Gogotsi, Nat. Mater. 7 (2008) 845-854.

[14] G. Wang, L. Zhang, J. Zhang, Chem. Soc. Rev. 41 (2012) 797-828.

[15] K.P. Lisha, S.M. Maliyekkal, T. Pradeep, Chem. Eng. J. 160 (2010) 432-439.

[16] M.A. Salam, Colloids Surf., A 419 (2013) 69-79.

[17] L. Della Puppa, M. Komarek, F. Bordas, J.C. Bollinger, E. Joussein, J. Colloid Interface Sci. 399 (2013) 99-106.

[18] W.F. Wei, X.W. Cui, W.X. Chen, D.G. Ivey, Chem. Soc. Rev. 40 (2011) $1697-$ 1721.

[19] X. Zhao, L. Zhang, S. Murali, M.D. Stoller, Q. Zhang, Y. Zhu, R.S. Ruoff, ACS Nano 6 (2012) 5404-5412.

[20] P. Lv, P. Zhang, Y. Feng, Y. Li, W. Feng, Electrochim. Acta 78 (2012) 515-523.

[21] Y.C. Chen, Y.K. Hsu, Y.G. Lin, Y.K. Lin, Y.Y. Horng, L.C. Chen, K.H. Chen, Electrochim. Acta 56 (2011) 7124-7130.

[22] W. Chen, R.B. Rakhi, L. Hu, X. Xie, Y. Cui, H.N. Alshareef, Nano Lett. 11 (2011) 5165-5172. 
[23] G.R. Li, Z.P. Feng, Y.N. Ou, D. Wu, R. Fu, Y.X. Tong, Langmuir 26 (2010) 2209 2213.

[24] Q. Cheng, J. Tang, J. Ma, H. Zhang, N. Shinya, L.C. Qin, Carbon 49 (2011) $2917-$ 2925.

[25] T. Boonfueng, L. Axe, Y. Xu, T.A. Tyson, J. Colloid Interface Sci. 303 (2006) 87-98.
[26] S.G. Wang, W.X. Gong, X.W. Liu, Y.W. Yao, B.Y. Gao, Q.Y. Yue, Sep. Purif. Technol. 58 (2007) 17-23.

[27] A.G. El-Deen, N.A.M. Barakat, H.Y. Kim, Desalination 344 (2014) 289-298.

[28] H. Zhang, M. Xu, H.J. Wang, D. Lei, D. Qu, Y.J. Zhai, Colloids Surf., A 435 (2013) $78-84$. 